VIII.-ON the Occtrrence of the Genus Listracanthes in the Englist Coal-measures.

\author{
By Herbert Bolton, F.R.S.E., \\ Assistant Keeper, Manchester Museum, Owens College.
}

$D^{0}$ URING the last few months two spines, or Ichthyodorulites, belonging to the genus Listracanthus, have come under my observation. Since both are well-preserved specimens, and not hitherto recorded from the English Coal-measures, some information as to their appearance and stratigraphical position may be of interest.

The genus Listracanthus was formed by Newberry and Wortben ${ }^{1}$ in 1870 to include small spines found in the Coal-measures of Illinois. These spines are small flattened structures, curved backwards, and with the sides ornamented by longitudinal ridges. The convex and concave margins are provided with acute spiny denticles.

Newberry and Worthen described only one species, L. hystrix (tom. cit., p. 372 , pl. ii, figs. $3,3 a$ ), to which $L$. Hildrethi was subsequently added by Newberry ${ }^{2}$ from the Coal-measures of Ohio, and $L$. Beyrichi ${ }^{3}$ by A. von Könen from the Coal-measures of Herborn, Nassau. An undescribed species is also recorded by A. Smith Woodward ${ }^{4}$ from the Calciferous Sandstone of East Kilbride, Lanarkshire; while others from the Upper Carboniferons Limestone Series of Belgium are noted by L. G. de Koninck. ${ }^{5}$

The larger of the two Lancashire specimens was found by me amongst the geological collections of the Royal Museum, Peel Park, Salford, when I was engaged upon their rearrangement. Although unlabelled, it fortunately happens that the spine lies upon the broken surface of an ironstone nodule, and is associated with Goniatites Listeri, G. atratus, Aviculopecten papyraceus, and numerous small ostracods. Ironstone nodules of this character are restricted in the Lancashire Coalfield to the roof of the Bullion or Upper Foot Mine of the Lower Coal-measures; hence the horizon of the specimen can be exactly determined. The second and smaller specimen is the property of Mr. Robert Cairns, of Ashton-under-Lyne, and was obtained by him from the marine band of the Middle Coal-measures in the River Tame at Dukinfield. It is enclosed in a nodule of earthy ironstone, and is unaccompanied by other fossils. I remember finding a third specimen ten years ago in the shales overlying the Bullion Coal of the Lower Coal-measures of Bacup, but it has since been lost.

Both the specimens now to be described differ from the three species hitherto defined, as well as from one another, but it is perhaps hardly justifiable to found a species upon the smaller specimen.

\footnotetext{
1 "Pal. Illinois," vol. iv, 1870 , p. 371.

2 Rep. Geol. Surv. Ohio, vol. ii, pt. 2, 1875, p. 56, pl. lix, fig. 6.

3 Neues Jahrb. 1879, p. 341, pl. vii, fig. 1 .

4 Catal. Foss. Fishes, B.M., pt. 2, 1891, p. 149.

5 "Faune Calc. Carbf. Belg.," pt. 1, 1878, p. 75, pl. v, fig. 11 .
} 


\section{Description of Specmens.}

\section{Listracanthus spinatus, sp.n.}

Diagnosis.-Spine small, not exceeding $19 \mathrm{~mm}$. in length, gently arched, sides flat, with seven longitudinal ridges, the convex and concave margins bearing acnte spine-like denticles. The denticles of the convex margin few in number and placed at equal distances apart, these pointing a little forwards and upwards, and the angle which they nake with the margin being not more than ten degrees. Only three denticles shown, but a fourth probably given off just above the 'broken upper edge. The first lateral ridge directly prolunged into the lowest denticle of the convex margin, the second ridge giving origin to the second and third denticles, and probably continuing upwards to a fourth (though a slight dislocation of the spine at this point prevents a clear determination). The denticles of the concave margin larger, stronger, and more numerous than those of the convex margin, and directed outwards at an angle fully double that of the latter. A cluster of tive spines placed at the base, in fan-fashion, the margin spreading out between them like a web.

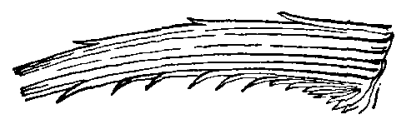

Listracantuus spinatus, sp.n. Lower Coal-measures, Lancashire.

Above the cluster are nine others at increasing distances apart. The lateral longitudinal ribs seven in number at the base, but only four continuing up to the broken apex. the remaining three running out into the denticles; all showing traces of slight nodular enlargements.

Observations. - The species thus described differs in several respects from all the known species, and is well characterized by . the differences of the denticles of the concave and convex margins, the slight nodulation of the lateral longitudinal ridges, and the fan-like expansion of spines at the base of the concave margin.

Horizon.-Roof of Bullion Mine, Lower Coal-measures.

Locality.-Lancashire.

Type in the Royal Museum, Peel Park, Salford.

2. Listracanthus, sp. indet.

Description. - Spine small, not exceeding $11 \mathrm{~mm}$. in length, arched, sides flat, with nine longitudinal ribs. Concave margin only bearing denticles, which are small, about twelve in number, and closely set. Convex margin entire.

Observations. - This specimen differs in several important features from Listracanthus spinatus. It is shorter, more arched, and broaler in comparison to the length, whilst only the concave margin bears denticles. So little is known of the nature and position of the two spines, that it may possibly be that the differences between them are only due to the position they occupied upon the body, and not to specific difference. Against this view must be placed 
the fact that one spine belongs to the Lower and the other to the Middle Coal-measures.

Horizon and Locality.-Marine band, Middle Coal-measures, River Tame, Dukinfield.

In conclusion, I desire to record my indebtedness to Mr. A. Smith Woodward, who first recognized the specimens as belonging to the genus Listracanthus.

\section{卫耳VI巴W}

I.-The Scenery of Switzerland and the Cadses to twich it Is DUE. By the Right Hon. Sir Joнn Lubвock, Bart., M.P., F.R.S., D.C.L., LL.D., F.G.S. 8vo, pp. xxxvi and 474 , with 154 illustrations in the text and one folding map of Switzerland. London: Macmillan and Co. (Limited), 1896.

7 HIS book, which was issued in July last, will have already found 1 its way into many an Alpine tourist's knapsack, and been read with pleasure in railway-train, or steam-boat, and in many a Swiss hotel and chalêt, by mountain and lake.

Its author's varied writings are already agreeably known to and welcomed by many thousands of our fellow-countrymen, both here and in greater England beyond the seas.

Whatever subject Sir John Lubbock takes up, he has the facility to communicate the results of his studies, his readings, and his observations, in an agreeable form to the public at large, who are only too delighted to be told facts in natural history, geology, or physical geography in clear and simple language, so that the reader need not fear to be carried beyond his depth by a too learned treatise, or told mere second-hand twaddle by an incompetent but too officious guide.

Sir John Lubbock is no mere tyro as a travelling companion to the Swiss Alps. He tells us, that as long ago as 1861, he had the pleasure of spending a short summer holiday in Switzerland with Huxley and Tyndall, and that from that day to this many of his holidays have been spent in the Alps. "On them," he adds, "I have enjoyed many and many delightful days; to them I owe much health and happiness. .... My attention was from the first directed to the interesting problems presented by the physical geography of the country. I longed to know what forces had raised the mountains, had hollowed out the lakes, and directed the rivers."

The author read much of what has been written about them; but, like all students, he wanted some book which should give him a short, comprehensive statement of the views of the various great authorities who had devoted their lives to the unravelling of the vast problems of the structure of the Alps, which might be useful to those travelling in Switzerland; but no such handy book was available.

At last, after much hesitation, Sir John Lubbock resolved to write such a work as he had himself felt the need of in the past, and so set to work, aided by such valuable help as could be obtained from Professor Heim, Sir John Evans, and others, and by making 